NBER WORKING PAPER SERIES

\title{
HISTORICAL NATURAL EXPERIMENTS: BRIDGING ECONOMICS AND ECONOMIC HISTORY
}

\author{
Davide Cantoni \\ Noam Yuchtman \\ Working Paper 26754 \\ http://www.nber.org/papers/w26754 \\ NATIONAL BUREAU OF ECONOMIC RESEARCH \\ 1050 Massachusetts Avenue \\ Cambridge, MA 02138 \\ February 2020
}

Prepared for the Handbook of Historical Economics. We thank the editors, Alberto Bisin and Giovanni Federico, for their advice and encouragement. Helpful and much appreciated suggestions and critiques were provided by Sascha Becker, Mathias Buhler, James Fenske, Joel Mokyr, Torsten Persson, and many seminar and conference participants. The views expressed herein are those of the authors and do not necessarily reflect the views of the National Bureau of Economic Research.

NBER working papers are circulated for discussion and comment purposes. They have not been peer-reviewed or been subject to the review by the NBER Board of Directors that accompanies official NBER publications.

(C) 2020 by Davide Cantoni and Noam Yuchtman. All rights reserved. Short sections of text, not to exceed two paragraphs, may be quoted without explicit permission provided that full credit, including ( $)$ notice, is given to the source. 
Historical Natural Experiments: Bridging Economics and Economic History

Davide Cantoni and Noam Yuchtman

NBER Working Paper No. 26754

February 2020

JEL No. B00,N00,N01,N10,O10

\begin{abstract}
$\underline{\text { ABSTRACT }}$
The analysis of historical natural experiments has profoundly impacted economics research across fields. We trace the development and increasing application of the methodology, both from the perspective of economic historians and from the perspective of economists in other subdisciplines. We argue that the historical natural experiment represents a methodological bridge between economic history and other fields: historians are able to use the cutting edge identification strategies emphasized by applied microeconomists; economists across subfields are able to scour history for useful identifying variation; development and growth economists are able to trace the historical roots of contemporary outcomes. Differences in fields suggest differences in scholars' aims of studying historical natural experiments. We propose a taxonomy of three primary motives that reflect priorities in different fields: historians aim to understand causal processes within specific settings. Economists across fields aim to identify "clean" historical events (in whatever context) to test hypotheses of theoretical interest or estimate causal parameters. And, growth and development economists aim to identify past variation that can be causally linked to contemporary outcomes of interest. We summarize important contributions made by research in each category. Finally, we close with a brief discussion of challenges facing each category of work.
\end{abstract}

Davide Cantoni

Seminar für Wirtschaftsgeschichte

University of Munich

80539 Munich

Germany

and CEPR

Davide.Cantoni@econ.lmu.de

Noam Yuchtman

London School of Economics

Houghton St.

London WC2A 2AE

United Kingdom

and CEPR

and also NBER

n.yuchtman@1se.ac.uk 


\section{Introduction}

The last 20 years have seen an extraordinary rise in the prominence of historical analysis in the broader economics profession (Abramitzky, 2015; Margo, 2018). It is easy to pick out historical work among the highest-impact research across fields in recent years, and much of this work relies on historical natural experiments: from economic growth and development (e.g., Acemoglu et al., 2001, Banerjee and Iyer, 2005, Nunn, 2008b, Dell, 2010), to health (Bleakley, 2007, Alsan, 2015), environmental economics (Hornbeck, 2012), economic geography (Davis and Weinstein, 2002; Bleakley and Lin, 2012), to macroeconomics (Imbens et al., 2001; Fuchs-Schündeln and Schündeln, 2005), and beyond 1

From the perspective of economic historians, the examination of historical natural experiments allows one to make causal arguments about historical processes using the language and empirical methods of applied economists more generally. From the perspective of economists across applied fields, historical variation provides a laboratory in which there exist unique opportunities to test hypotheses that cannot be tested using naturally-occurring contemporary variation or experimental methods. The study of specifically historical natural experiments also allows sufficient time to pass to observe general equilibrium effects. Natural experiments in history are a methodological "bridge" between economic history and other fields: historians' empirical methods have converged toward those in other applied microeconomic fields; scholars in other fields have developed the archival research skills of the economic historian.

We believe this bridge between fields has been extraordinarily valuable: historical natural experiments have allowed economic historians, development economists, and economists more generally to pose big questions while still attaining the identification of causal effects that is emphasized in modern empirical microeconomics Angrist and Krueger. 1999: Angrist and Pischke, 2010). Perhaps in no field has the examination of historical quasi-experimental variation been more influential than in economic growth and development: historical natural experiments have allowed scholars to identify plausibly fundamental factors - for example, political institutions and culture - using the causal, experimental language central to empirical work in (micro)economic development (as pioneered by Duflo, 2001, Miguel and Kremer, 2004, and Gertler. 2004, among others). The combination of big questions and careful causal identification explains this approach's impact across fields.

In this chapter we begin by tracing the development and increasing application of the natural historical experiment methodology, both from the perspective of economic historians and from the perspective of economists in other subdisciplines. Interestingly, the rise of the historical natural experiment reflects changes in fields as diverse as labor economics, economic history, and

\footnotetext{
${ }^{1}$ Of course, economic history continues to be influential beyond the application of historical natural experiments. Recent, important descriptive historical work exists e.g. in finance (Frydman and Saks, 2010), labor (Abramitzky et al. 2012), and public economics (Piketty and Saez. 2003: Piketty et al. 2006), among others.
} 
economic development.

Building on this intellectual history of the methodology, we propose a taxonomy of three primary motives for examining historical natural experiments. The taxonomy divides the literature into categories that reflect different priorities and objectives in different fields. The different objectives are reflected in the breadth and depth of the historical analysis, as well as in the empirical challenges facing different analyses.

(1) Experiments to understand history. A first set of research, typically conducted by economic historians, is primarily motivated to understand a specific historical episode or process. Scholars producing this sort of research will naturally seek historical experiments within their pre-specified setting. Rather than aiming at testing a general economic hypothesis, they aim to make more compelling causal arguments about the setting or process of interest (perhaps with more general implications). Examples of this sort of work are the research by Heldring et al. (2017), who study R.E. Tawney's famous hypothesis about the "Rise of the Gentry" and its relationship to industrialization, or our own work on medieval universities (Cantoni and Yuchtman, 2014), aiming to understand the causal effect of universities and legal institutions on the Commercial Revolution. A study of the historical context helps identifying plausibly exogenous variation - variation in the presence of dissolved monasteries in England, or variation in university establishment in 14th century Germany resulting from the Papal Schism.

(2) Experiments to understand economics. A second set of research, produced by economists across fields, aims primarily to answer a theoretical or empirical question in an economics subdiscipline, then identifies a historical source of variation that can test theory or provide a clean estimate of an empirical parameter. The specific historical setting is not of interest per se, but one must carefully apply historical methods to identify and collect data and - most importantly — to argue for the exogeneity of the historical treatment. Examples of this work include Bernhofen and Brown (2004, 2005), who test the theory of comparative advantage examining the forced opening of the Japanese economy in the late 1850s. Their work is not written as an economic history of the Japanese economy, but as a remarkably clean test of trade theory.

(3) Experiments to understand contemporary outcomes. Finally, a third set of research, produced mainly by growth and development economists, aims to understand contemporary economic development outcomes by looking at the past $\left.\right|^{2}$ Identifying the causal role of past events whether directly, or through an intermediating variable - requires identifying historical quasiexperimental variation. While scholars typically have a specific set of historical factors they wish to understand, their interest is primarily in linking variation in the past to outcomes in the present.

\footnotetext{
${ }^{2}$ Scholarship identifying deep historical roots of contemporary development shares its methods with work documenting the persistence of historical cultural traits. Among other important findings are: persistence of anti-Semitism (Voigtländer and Voth, 2012); persistence of gender norms (Alesina et al. 2013); and, persistence of fundamental economic preferences (Galor and Özak 2016). Research in this field is focused on linking spatial (or cross-group) patterns of cultural traits and historical features across time, and relies less on historical natural experiments changing cultural traits (though exceptions exist, e.g. the work by Nunn and Wantchekon, 2011 on the effect of the slave trade on trust in Africa).
} 
Specific sources of historical variation are selected both for their possible long-term impact and for the plausibility of the assumptions needed to identify causal effects. An example of this is the work of Dell (2010), which identifies the persistent effect of a coercive labor institution (colonial Peru's mining mita) on contemporary economic development outcomes. Dell's work includes an extremely rich historical analysis of its setting; yet it is the sharp geographical variation in institutions which makes the context of the mita particularly suitable for this study, compared to other - possibly equally important, but less sharply bounded - instances of extractive colonial institutions in the Americas.

It is important to highlight two characteristics of our taxonomy: first, it is not exclusive, as there are no bright lines dividing work into the three categories we describe. We apply the taxonomy in the belief that most research more naturally fits into a single category, rather than the others, but many papers will have elements of multiple categories. For example, work in category (1) is characterized by a primary motivation to understand a specific historical process. But, work in this category may well speak to some general economic questions, which are the primary driver of work in category (2). Work in categories (2) and (3), including Dell's (2010) work, makes significant contributions to our understanding of a specific historical process even if the research may not have initially been motivated by the desire to understand the specific historical setting on which the author focuses.

A second important note about our taxonomy is that the existence of different motives for undertaking the study of historical natural experiments does not imply in any way the existence of better or worse motives. All of the work we highlight here makes deep, important social science contributions by combining careful applied econometric analysis of natural experiments with careful historical research. The emphasis on understanding historical episodes themselves versus general phenomena, versus contemporary outcomes varies, but we learn a great deal from all three categories of work (including about history).

Research in each category has made important contributions, which will be reviewed below. Economic history research in category (1) has produced important steps forward in our analysis of historical experiences, from the Neolithic Revolution (Matranga, 2017), to the Columbian Exchange (Nunn and Qian, 2011), to the Marshall Plan (Giorcelli, 2019). Research in category (2) has provided some of the cleanest tests of economic theory: from evidence of the efficacy of infant industry protection (Juhász, 2018), to the existence of urban agglomeration effects (Bleakley and Lin, 2012), to the incorporation of news in asset prices (Koudijs, 2016). Finally, research in category (3) has significantly broadened economic development research beyond the (valuable) work conducted implementing randomized controlled trials (RCT's) and has also impacted development policy. Not only do scholars and practitioners now have a better appreciation for the historical legacy of colonialism and slavery (see, e.g., Acemoglu et al., 2001; Acemoglu et al., 2002; Nunn, 2008b; Feyrer and Sacerdote, 2009; Iyer, 2010; Lowes and Montero, 2018); but they also are more focused on the importance of historically-rooted culture and political institutions, and their 
expression in contemporary state governance $\mathrm{H}^{3}$

In what follows, we first offer a brief intellectual history of the rise to prominence of the historical natural experiment. Next, we provide a review of the research contributions made in each category of our taxonomy. We then provide a brief discussion of empirical challenges facing each category of work (which we develop further in Cantoni and Yuchtman, 2020), then offer some concluding thoughts.

\section{How Did We Get Here?}

We see the increased analysis of historical natural experiments as the outcome of changes across multiple fields in economics. We first discuss these changes in the fields of labor economics, economic history, and growth and development economics, and we argue that they can be mapped to the three types of papers based on historical natural experiments delineated in the taxonomy above. We then describe a particularly influential strand of research - on the causal effect of political institutions on economic development — which brought these three developments together.

\section{Labor Economics and the Credibility Revolution}

The "credibility revolution" (Angrist and Pischke, 2010) across applied microeconomics has pushed economists across fields to find credible sources of (experimental or quasi-experimental) variation to answer their research questions. Some of the earliest "quasi-experimental" work in labor economics had the flavor of studying historical natural experiments. Angrist (1990) identified the causal effect of military service on earnings by exploiting the Vietnam-era draft of US men, which implemented a lottery across men's birth dates. Angrist and Krueger (1991) study the effects of compulsory schooling laws - in conjunction with quasi-random variation in individuals' birth dates - to estimate the causal effect of schooling on earnings.

Both of these papers are the outcomes of searching the past and present for variation that can identify the causal effects of interest. Quite simply, historical variation in public policies, historical human-made events, and historical natural processes all provide sources of variation that may provide cleaner tests of theory or better opportunities to estimate an important empirical causal parameter than any contemporary variation allows for. This was recognized early on by labor economists, then increasingly appreciated across applied microeconomic fields. The labor economics-led credibility revolution was thus a driving force of the analysis of historical natural

\footnotetext{
${ }^{3}$ In planning its post-2015 development agenda, the United Nations writes that its framework "must be based on an understanding of the importance of, and a commitment to further promote, resilient, legitimate and inclusive national and local institutions, as well as inclusive participation in public processes. It must address institutional and governance bottlenecks to ensure transformative and sustainable development." This echoes the arguments of Acemoglu and Robinson (2012). Development research on governance more generally is summarized in Finan et al. (2017). The UN report can be found at https://www . un.org/millenniumgoals/pdf/Think\%20Pieces/7_governance.pdf.last accessed October 10, 2019.
} 
experiments across the discipline. Research in our taxonomic category (2) very naturally arises from the credibility revolution across the discipline: economists are increasingly looking across space and time to identify the ideal source of variation to test a hypothesis or estimate a causal parameter.

\section{Economic History Beyond the Cliometric Revolution}

The decades leading up to the increased application of historical natural experiments saw the convergence of empirical work in economic history toward the practices of applied microeconomics more generally. This convergence dates back to the cliometric revolution of the 1960s, which brought quantitative analysis and regressions into economic history research (see perhaps its bestknown example, Fogel and Engerman's, 1974, Time on the Cross). The convergence has continued with the increasing availability of data due to digitization; this set the stage for the adoption of the credibility revolution within economic history itself $4_{4}^{4}$ Research in our taxonomic category (1) thus arises from the incorporation of the credibility revolution into quantitative economic history: economic historians trained in economics will naturally try to make causal arguments about the past using the quasi-experimental methods taught in all major graduate programs, and applied in other fields.

\section{Economic Development and the Randomization Revolution}

The early 2000's saw the rise of randomized controlled trials (RCTs) and impact evaluation as the "gold standard" in empirical economic development research (Gertler, 2004; Miguel and Kremer, 2004, Banerjee and Duflo, 2009a). While RCTs were undoubtedly a huge step forward in the analysis of economic development, there was a tendency for something of a "streetlight effect" (Deaton, 2010): a focus on the types of questions that could be answered by conducting an RCT. This can lead to the neglect of explanatory variables of interest that cannot be randomized because of ethical constraints; funding constraints; or logistical constraints. In such a setting, identifying the causal effects of some of these difficult to randomize variables of interest by examining natural experiments provided by history held the promise of answering big questions with credible identification. There was thus a gap in the development and growth literature that the analysis of historical natural experiments could fill. Research in our taxonomic category (3) is closely linked to this desire to identify the ultimate drives of economic growth, while adhering as closely as possible to the causal identification standards expected by development economists, whose benchmark was the RCT.

\footnotetext{
${ }^{4}$ See Abramitzky (2015), Margo (2018), and Jaremski (2020), for a discussion of recent changes in the position of economic history within the economics discipline; see also Mitchener (2015), Abramitzky et al. (2019), and Zhang et al. (2019) on the promise of digitized historical data for economic history. A prior, optimistic assessment of the integration of economic history into the economics profession is contained in Romer (1994), contrasting the older, more pessimistic view of McCloskey (1976).
} 


\section{The Confluence of These Currents}

The application of the historical natural experimental methodology in the subfield of economic growth and development reflects all three of the trends above, and has produced one of the most influential economics articles of recent decades: Acemoglu, Johnson, and Robinson's (2001), “The Colonial Origins of Comparative Development" (over 13,000 Google Scholar citations as of January 2020).

A crucial precursor to economists' use of the historical natural experiment to understand the causes of economic development was Jared Diamond's (1997) Guns, Germs, and Steel. This work asked deep questions about fundamental drivers of economic success across societies, pointing to ancient historical roots of contemporary riches and poverty. The work also took something of an "experimentalist" approach to understanding historical development: Eurasia differed from the Americas and Africa in having an orientation on the x-axis; Eurasia also happened to have more species of domesticable plants and animals in its natural resource endowment than other continents. This "historical natural experiment" - the quasi-random assignment of species across space; of geographic connections across space - arguably shaped paths of human development for thousands of years. $5^{5}$

From the perspective of economics and economic history, taking a similar approach, Engerman and Sokoloff (1997), too, argue that contemporary development outcomes were fundamentally shaped by geography and historical experience. Working within the cliometric tradition, they provide a richer social science structure for linking geography to development, highlighting the path from geographical endowments - e.g., suitability for plantation agriculture in the Americas - to political and economic institutions - e.g., slavery - to contemporary poverty. They, too, apply an experimental lens to the analysis of history and development, viewing the Americas' colonization as an experiment in which agricultural suitability varies, allowing for the identification of causal forces.

Drawing from these early analyses of historical natural experiments, Acemoglu et al. (2001) examine the impact of (arguably exogenous) historical settler mortality across space on contemporary development, working through the historical and contemporary political institutions developed in different colonies ${ }^{6}$ Acemoglu et al. (2001) build on Engerman and Sokoloff's work by: (i) examining a global sample of countries; (ii) applying a canonical, large- $n$, quantitative analysis (i.e., the cross-country growth regression pioneered by Barro, 1991, and Mankiw et al., 1992); and, (iii) explicitly formulating a quasi-experimental (instrumental variables) identification strategy for studying the causal effect of contemporary political institutions (resulting from historical variation in settler mortality and thus colonial settlement strategies and historical political institutions) on

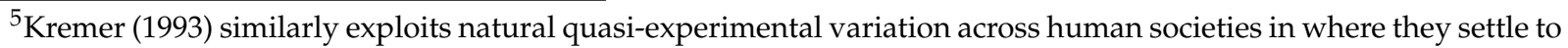
study the causal effect of population size on technological progress. The concept of historical natural experiments, and in particular the use of humankind's expansion across the world as a major experiment, is further explored in Diamond and Robinson, eds (2010) from the perspectives of various social science disciplines.

${ }^{6}$ This work is then developed in Acemoglu et al. (2002) and generalized in Acemoglu and Robinson (2012).
} 
development.

This work powerfully unites the three currents described above. First, the developments of quantitative economic history: its reference to the cliometric literature of Engerman and Sokoloff (1997) and its archival research on settler mortality. Second, the implementation of credible, quasiexperimental research design emphasized in modern applied microeconomics. Third, a compelling fusion between the big picture, cross-country macroeconomic analysis of growth (e.g., Barro, 1991), and the experimental emphasis in recent microeconomic work on economic development (summarized in, e.g., Banerjee and Duflo, 2009b).

\section{What Have We Learned?}

As described in the introduction above, we propose a taxonomy of papers relying on historical natural experiments, based on their major focus and their epistemological objective: (1) papers that seek to understand a specific historical episode or process; (2) papers that aim to answer a (theoretically-founded) question in economics through a historical episode; (3) papers that aim to understand contemporary development by examining historical factors. Each category of work in our taxonomy has yielded a range of powerful insights: teaching us about history, about economic processes, and about the sources of income variation across countries. Importantly, boundaries between these categories are fluid, and many of the papers in this literature will provide different layers of insights, and not fall unambiguously into exactly one of the categories.

In the following, we sketch out some of the most impactful work in each of areas. The work we cite implements a variety of empirical strategies: from differences in differences, to instrumental variables, to regression discontinuity. Our definition of what constitutes a "(historical) natural experiment" is thus not limited to a narrow set of econometric methods, but rather encompasses any historical imposition of a "treatment", evaluated relative to some counterfactual or control group 7 The sources of quasi-experimental variation also vary: from literal lotteries to historical policies, to natural events, to spatial variation, sometimes smooth and sometimes sharp.

\subsection{Experiments to Understand History}

We present work falling into this category chronologically, in historical order, illustrating the remarkable scope of this body of work.

\footnotetext{
${ }^{7}$ Sometimes the "treatment" consists of the abolition of a pre-existing form of variation: e.g., the eradication of hookworm (Bleakley, 2007). In this case, variation in the intensity of the treatment comes not from the application of the treatment itself, but from the pre-existing distribution of the condition. The treatment can thus be interpreted as a historically-contingent effect of a pre-existing feature. We discuss the econometric challenges of this, and related, empirical research designs in Cantoni and Yuchtman (2020).
} 


\section{The Neolithic Revolution}

Matranga (2017) studies the effects of seasonality on the development of settled agricultural societies, exploiting natural variation in seasonality across space - which sharply increased as a result of exogenous oscillations in Earth's axis around 12,000 years ago. He finds that greater seasonality is, indeed, associated with the development of settled agricultural societies. He argues that this is due to the need to store food when climate is highly seasonal: a given crop will grow in a location in a particular season, but during other seasons, stored food may be needed. Providing corroborating evidence for a mechanism emphasizing the need to store food in highly seasonal environments, Matranga exploits the fact that local crop diversity (and thus year-round food availability) is greater when there is more local variation in elevation. Consistent with his theory, seasonal areas with more variation in elevation are not as likely as other seasonal areas to develop settled agricultural societies. Matranga's work provides a compelling causal argument for one of human society's most important developments.

\section{The Commercial Revolution}

In our work on medieval universities (Cantoni and Yuchtman, 2014) we aimed to understand the causal effect of universities and legal institutions on the European Commercial Revolution. Exploiting the exogenous establishment of the first universities in Germany - a result of the Papal Schism - we show that greater access to a university increased human capital accumulation, particularly legal human capital, and also increased the rate of market establishment. The rise of an urban, commercial European economy, we argue, was causally shaped by Europe's universities, and the legal training they provided. Legal training reduced the costs of trade and contract enforcement in an environment that was highly politically fragmented.

\section{The Invention of the Printing Press}

The invention of the printing press by Gutenberg was arguably among the most important single innovations in world history. But identifying its causal effects proved difficult for economic historians. Dittmar (2011) provides credible evidence that the printing press caused European cities to grow. He exploits the quasi-random diffusion of the press from its initial location, in Mainz. Building on this work, Dittmar and Seabold (2018) aim to study the impact of the quantity of printing on both economic and cultural change in early modern Europe. They discovered that printers' deaths increased printed output due to the unraveling of collusion among printers. Exploiting the quasi-random increase in printing following printers' deaths, they show that increased printed output increased economic activity (likely working through the spread of business knowledge) and induced social change (the adoption of the Reformation). In addition to Dittmar's work (and exploiting similar variation), Rubin (2014) presents evidence that the printing press supported the rapid spread of the Protestant Reformation across Europe. 


\section{The Protestant Reformation}

As one of the turning points of Western European history, the Protestant Reformation naturally lends itself to be examined as a historical natural experiment. Cantoni et al. (2018) present evidence that the Reformation led to the reallocation of economic resources from religious uses (e.g., the construction of churches and monasteries) to secular uses (e.g., the construction of administrative buildings). Hornung (2014) shows that the Protestant Huguenots expelled from France produced a more productive industrial sector in Prussia in the 18th century ${ }^{8}$

Other work has tackled one of the best-known theories in social science, the Weber Hypothesis, postulating that Protestant regions were richer than Catholic ones due to a specific work ethic. Exploiting the quasi-random diffusion of Protestantism from Luther's home of Wittenberg, Becker and Woessmann (2009) find that Protestantism was associated with economic development in late 19th century Prussia, but contrary to Weber's argument, this was likely not due to cultural differences. Differences in economic development are instead accounted for by the greater human capital in Protestant regions 9 Cantoni (2015) finds no difference in economic development between Catholic and Protestant cities across the entire period from 1500-1900.

\section{The Columbian Exchange}

One of the most important transfers of people, plants, animals, and microorganisms in human history was the "Columbian Exchange" between the Old World and the New World following Europeans' conquest of the Americas. Nunn and Qian (2011) argue that among the most profound consequences of this exchange was the adoption of the potato in Old World agriculture. The potato is an extremely inexpensive source of nutrition, where it can be grown. Exploiting quasi-random geographic variation in potato crop suitability, Nunn and Qian (2011) show that potato-suitable regions differentially grew compared to other regions, specifically after potato adoption occurred - the potato can account for one-quarter of the growth in Old World population between 1700 and 1900. Jia (2014b) presents evidence that the adoption of the sweet potato in China (another crop introduced from the new world) mitigated the effects of adverse agricultural productivity shocks and thus reduced the frequency of civil conflict.

\section{The French Revolution}

The French Revolution and subsequent Napoleonic Wars have long been viewed by historians as among the most consequential historical episodes in European history. Acemoglu et al. (2011a) identify the causal effect of Napoleon's conquest of much of Europe by examining quasi-random,

\footnotetext{
${ }^{8}$ In related work, Iyigun 2008 finds that religious conflict with the Islamic World reduced conflict between Protestants and Catholics in Europe.

${ }^{9}$ In other work on the economic consequences of religion, Botticini and Eckstein (2007) examine the historical roots of the Jewish people's economic specialization and emphasis on human capital accumulation.
} 
within-Germany variation in the extent of French occupation. They find that the reforms introduced by Napoleonic conquest causally shaped economic development trajectories. Specifically, radical institutional reform established conditions that led to more rapid growth following the onset of the Industrial Revolution.

\section{The Industrial Revolution}

The Industrial Revolution is one of the most studied episodes in the field of economic history, but its unique status in history - arising only once - has made it challenging to study as a "large-n" historical natural experiment. Recent work exploiting historical natural experiments has provided some insight into the Industrial Revolution's rise and spread, as well as how the Industrial Revolution economy functioned.

Fernihough and $\mathrm{O}^{\prime}$ Rourke (2014), with an empirical approach explicitly modeled on the work of Nunn and Qian (2011), find a significant causal effect of coal availability on city growth during the time of the Industrial Revolution, suggesting an important geographic component to the distribution of industrial development. Heldring et al. (2017) find that the presence of "gentry" elites, rather than the traditional aristocracy, was associated with more industrial employment and mills during the Industrial Revolution in England and Wales. Squicciarini and Voigtländer (2015), collecting data on the regional distribution of subscribers to Diderot's Encyclopédie, identify the role of upper tail human capital in driving France's industrialization. Naidu and Yuchtman (2013) study the functioning of labor markets in Industrial Revolution Britain, regulated by Master and Servant law, which limited labor mobility. They find that exogenous labor demand shocks strongly increased prosecutions, but did not produce monotonic effects on wages: prosecutions under Master and Servant law reduced mobility and thus limited the variation in wages. 10

\section{The Progressive Era's Investments in Public Health}

The late nineteenth and early twentieth century US saw many "Progressive Era" public health initiatives, and scholars have exploited quasi-experimental variation arising from these to shed light on their consequences. Examining variation across the US South in exposure to hookworm infection, Bleakley (2007) finds that eradication of the hookworm disease in the early twentieth century significantly increased educational investments. Alsan and Goldin (2019) study the consequences of sewerage and clean water infrastructure for mortality. They exploit variation across Boston-area municipalities in their timing of joining the (Boston) Metropolitan Sewerage District, and find that the combination of sewerage and clean water was a major factor in reducing child

\footnotetext{
${ }^{10}$ An often-cited precondition for the British Industrial Revolution was the ability of merchants to protect their property rights from the monarch (Acemoglu et al. 2005). Jha (2015) studies the process through which property rights protection was achieved, presenting evidence that individuals with a (quasi-randomly assigned) stake in overseas trading companies differentially opposed the extractive Charles I during the English Civil War.
} 
mortality in turn of the 20th century Massachusetts ${ }^{11}$

\section{The Great Migration}

Hornbeck and Naidu (2014) identify the causal effect of one of the great demographic shifts in American history: the Great Migration of Black Americans northward from the US South. To identify the causal effect, they exploit quasi-random variation in the intensity of the Great Mississippi flood of 1927. More intensely flooded areas saw significantly more Black outmigration. Whites attempted to restrict Black outmigration, but in the long run adjusted by adopting new agricultural technologies. Interestingly, technology adoption made more affected regions more productive than less flooded regions in the long run. Boustan (2010) studies the impact of the Great Migration on the residential segregation of American cities. Implementing a shift-share approach that relies on pre-existing black populations in Northern cities and variation in economic conditions across the US South, she estimates large effects of black migration on "white flight" from the inner cities 12

\section{The Great Depression}

Work on the Great Depression was among the first to explicitly exploit natural experiments to understand important historical episodes. Most famously, Friedman and Schwartz (1963) examined policy experiments that varied the money supply and used them to argue for a "monetarist" interpretation of the Depression's severity. Richardson and Troost (2009) exploit the division of the state of Mississippi between two Federal Reserve banks - which differed in their monetary policy in response to a 1930 bank crisis - to identify the importance of regional Federal Reserve policies to the Depression. Hausman et al. (2019) exploit variation across space in agricultural production to identify the effect of dollar devaluation on crop prices, incomes, and consumption. They find that the "farm channel" played an important role in the 1933 recovery from the Depression. Finally, Kline and Moretti (2014) study the effects of the Tennessee Valley Authority (TVA), a major public works program enacted in response to the Depression. Comparing TVA counties to counties in proposed, but not enacted regional authorities, they find a significant, persistent effect of this major economic stimulus program on manufacturing.

\footnotetext{
${ }^{11}$ Unintended consequences arising from public health programs include exposing individuals to lead (studied by Clay et al. 2014) and allowing studies such as the infamous "Tuskegee Study of Untreated Syphilis in the Negro Male," which (in addition to its horrific direct consequences from leaving Syphilis untreated) generated persistent adverse health consequences for Black men (Alsan and Wanamaker. 2018).

${ }^{12}$ In related work, Fouka et al. (2019) find that the Great Migration fostered the integration of previously-marginalized recent immigrants from Southern and Eastern Europe.
} 


\section{The Holocaust}

The Holocaust was one of the worst atrocities of the 20th century. Acemoglu et al. (2011b) show that the effect of murdering Jews was not only a humanitarian catastrophe, but also had persistent economic costs. The wiping out of the disproportionately "middle class" Jewish population distorted Russia's social structure and economy, and made Russian regions persistently poorer decades later.

\section{The Marshall Plan}

The economic recovery of Europe following World War II (WWII) was one of the first-order facts of the postwar era. Giorcelli (2019) identifies the causal effect of one program through which the United States helped stimulate the European economy: management and technology transfers to Italian firms. Exploiting the quasi-random restriction of the program (resulting from an unexpected budget cut), she finds that firms exposed to the management and technology transfer had higher performance than comparison firms for more than a decade ${ }^{13}$

\section{Social Movements in the Post-WWII US}

The post-WWII US saw the rise of the Black Civil Rights movement, which culminated in the Civil Rights Act of 1964 and the Voting Rights Act of 1965. Cascio and Washington (2014) show that the enfranchisement of Black Americans under the 1965 Voting Rights Act produced a shift in public expenditure towards counties with more Black citizens. Aneja and Avenancio-Leon (2019) show that the Voting Rights Act led to greater hiring of Blacks into public offices, which contributed to Black-White wage convergence ${ }^{14}$

The post-War era also saw great strides toward socioeconomic equality for US women. Goldin and Katz (2002), Bailey (2006), and Bailey (2010) document that a key cause of greater socioeconomic equality was access to contraception technology, specifically "the Pill." Exploiting crosscohort, cross-region variation in access to contraception, they find that it reduced and deferred women's fertility; increased educational attainment; and led to greater selection of women into the highly-skilled professions.

\footnotetext{
${ }^{13}$ Another notable post-WWII program was the US GI Bill, which paid for higher education for returning American soldiers. Stanley (2003) presents evidence that exposure to the GI Bill had economically significant effects on postsecondary schooling.

14 Aaronson and Mazumder (2011) study an earlier episode of Black-White socioeconomic convergence, the effects of the Rosenwald School initiative, which constructed 5,000 schools for Black children in the US South. Exploiting quasi-random variation in exposure to the schools across cohorts and counties, they find that the Rosenwald program produced meaningful socioeconomic impacts for affected Black students: school attendance, literacy, years of schooling, cognitive test scores, and northern migration all increased.
} 


\subsection{Experiments to Understand Economics}

Work in this category primarily aims at the empirical verification of a fundamental economic theory or concept (often in the form of an "existence" proof), or estimating a specific causal parameter (either of theoretical interest or policy relevance). To illustrate the breadth of the contributions made in this category of work, we will organize this section by economics subfield.

\section{General economic theory}

Fundamental economic theories have been tested by scholars exploiting historical natural experiments. The importance of secure property rights - whether enforced privately or by the state for incentivizing investment has been examined by various scholars. Hornbeck (2010) exploits quasi-experimental variation in the adoption of barbed wire to enforce property rights across space; Bühler (2019) shows that regulating access rights to grazing districts increases productivity relative to open-access rangeland, using a discontinuity generated by the 1934 Taylor Grazing Act. The work by Libecap and Lueck (2011) and by Bleakley and Ferrie (2014) reveals the importance of initial allocations of property rights, and their effects on land values.

How does the arrival of new, private information get incorporated into prices? Koudijs (2016) exploits variation in the arrival of information to the 18th century Amsterdam stock market, arising from variation in wind that delayed the arrival of information-bearing boats from England. Koudijs finds that share prices significantly react to information arrival, consistent with financial economic theory. Dube et al. (2011) also find that new information sharply moves stock prices, exploiting a different source of information: leaks of classified information about American covert operations - planned coups - that had the potential to produce high returns to companies in the targeted countries ${ }^{15}$

Another area of research considering basic questions in economic theory regards preference formation. An active area of research examines historical natural experiments to study whether individual experience shapes preferences. Exploiting the division of Germany between East and West, Alesina and Fuchs-Schündeln (2007) show that the experience of Communism persistently shaped preferences for redistribution and state intervention in the economy. Malmendier and Nagel (2011) show that the experiences of high stock returns (to which individuals are exposed quasi-randomly depending on their cohort) affect one's willingness to take financial risks. Koudijs and Voth (2016) show that (quasi-random) personal exposure to risk of significant losses affected 18th century Dutch investors' willingness to take subsequent financial risks. Giuliano and Spilimbergo (2014) show that experiencing a recession in one's formative years affects one's beliefs about the world and preferences for redistribution.

\footnotetext{
${ }^{15}$ The value of private information has also been studied in the context of research on auctions incorporating historical natural experiments (Hendricks and Porter, 1988 and and Hendricks et al. 2003). Craft (1998) and Feigenbaum and Rotemberg (n.d.) identify the value of greater access to information in the context of the creation of the US Weather Bureau and Postal Service, respectively.
} 


\section{Labor Economics}

In one of the earliest papers exploiting a credibly causal research design based on a historical natural experiment, Angrist (1990) studies the causal effect of military service on earnings. To overcome the endogeneity of military service, he exploits the Vietnam War draft lottery that randomly increased the probability that men with certain birthdates would serve. Angrist finds that military service is causally associated with a significant earnings penalty for white men. To study the effects of low-skilled immigration on local wages, Card (1990) exploits the arrival of over one hundred thousand Cuban migrants' arrival in Miami as part of the Mariel Boatlift in 1980. He compares Miami's labor market outcomes following this "natural experiment" to those in other cities and finds very small effects. Angrist and Krueger (1991) study the effects of compulsory schooling laws - in conjunction with quasi-random variation in individuals' birth dates - to estimate the causal effect of schooling on earnings (see also Stephens and Yang, 2014).

Determinants of human capital investments have also been studied by exploiting historical natural experiments. Santavirta (2012) studies the role of families in shaping human capital outcomes by exploiting quasi-random variation in children's adopted families in World War II era Scandinavia. Exploiting variation across US states in the legal minimum working age, Manacorda (2006) studies the effects of local labor market opportunities for children on their siblings, finding that working children improve their siblings' educational outcomes. Using an almost archetypal natural experiment - Georgia's Cherokee Land Lottery of 1832 - Bleakley and Ferrie (2016) show that substantial wealth transfers do not lead the children of lottery winners to obtain better outcomes in terms of wealth, income, or literacy.

A large literature studies the determinants of health and the consequences of variation in health - an important dimension of human capital - and historical natural experiments have proved to be particularly useful to study the "Fetal Origins" hypothesis. Almond (2006) finds that fetal exposure to the 1918 flu epidemic worsened a range of human capital and economic outcomes. Examining individuals who experienced the eradication of malaria in India during their early childhood, Cutler et al. (2010) find small, positive effects on income in adulthood, but only mixed results on educational attainment. Banerjee et al. (2010) identify the effect of a temporally and spatially varying agricultural productivity shock (phylloxera, which destroyed vineyards in nineteenth century France and reduced farmers' incomes) on height outcomes, finding large effects. Baten et al. (2014) study the impact of high food prices in early 19th-century Britain, caused by bad harvests and the interruption of grain imports from France during the Continental Blockade, on cognitive outcomes in adulthood. They find that individuals born in years with high food prices had lower levels of numeracy and worked in occupations with lower earnings. Exploiting Sweden's rich administrative data, Almond et al. (2009) find that fetal exposure to fallout from the Chernobyl disaster affected academic performance; Grönqvist et al. (2020) find significant effects of fetal exposure to lead; and, Nilsson (2017) finds significant effects of fetal exposure to alcohol. 
Exploiting changes in air pollution driven by the 1970 Clean Air Act, Isen et al. (2017) find that labor market outcomes are affected by exposure to air pollution in the first year of life.

Marriage markets have also been studied by exploiting historical natural experiments. Scarcity of men induced by military casualties has been studied by Abramitzky et al. (2011) and Brainerd (2017), among others. In different contexts, theoretical predictions about male scarcity are confirmed: men achieve better matches; women's marriage rates fall; and, out of wedlock births rise. Goñi (2018) considers the "London Season", in which aristocratic bachelors were introduced to "eligible" debutantes. The exogenous interruption of this matching technology (e.g., due to the death of Prince Consort Albert) reduced the extent of sorting in the marriage market.

Finally, personnel economics questions have been answered using historical natural experiments. $\mathrm{Xu}$ (2018) exploits variation at the top of the British Colonial Office to study the effects of patronage on bureaucrat performance. He finds that a patron leading the Colonial Office produces more desirable placements, and worse performance. In a different historical context, the British Royal Navy, Voth and $\mathrm{Xu}$ (2020) find that patronage produces promotion, but in this case better selection and better performance.

\section{Public Finance}

The causal effects of the introduction of major social welfare programs have been evaluated exploiting historical natural experiments. Aizer et al. (2016) consider the effects of the Mothers' Pension program - one of the first government-sponsored welfare programs in US history. Using individual-level administrative records of applicants to the program they show that children of the beneficiaries have improved health and higher income in the long run. Gelber et al. (2016) study the effects of additional Social Security income on earnings, exploiting a sharp change in benefits depending on birth year. Goodman-Bacon (2018) studies the effects of Medicaid's introduction, exploiting variation across states in the ex ante eligible population, and finding that it significantly reduced child mortality. Fetter and Lockwood (2018) exploit variation in Old Age Assistance Programs across US states and find that these programs significantly reduced older men's labor force participation rates. Combining the study of the "Fetal Origins" hypothesis with the evaluation of a major welfare program, Almond et al. (2011) find that the rollout of the Food Stamp Program improved birth outcomes, especially among the African American population. Studying Bismarck's health insurance - the oldest compulsory health insurance program - Bauernschuster et al. (2020) find that its introduction reduced mortality rates from infectious diseases.

In addition to studying government expenditure programs, several studies have examined major historical tax reforms to estimate the impact of tax rates on labor supply (e.g., Feldstein. 1995 and Bianchi et al. 2001). 


\section{Trade Economics}

The theory of comparative advantage is central to trade theory, yet it is difficult to test. Bernhofen and Brown (2004) and Bernhofen and Brown (2005) identify a setting of exogenous trade opening: the forced opening of the Japanese economy in the late 1850s. They provide the cleanest empirical evidence available on the causal effect of openness on trade volume (exports and imports), prices, and welfare. They also confirm the predictions of one of the most important theories in economics.

The relationship between distance and trade volume is at the heart of empirical trade research. Feyrer (2009) exploits the closure of the Suez Canal between 1967 and 1975 - and the resulting sharp change in shipping distances between trading partners - to identify the causal effect of distance on trade and incomes. He finds that greater distance reduces trade, and thus income. Pascali (2017) exploits the invention of the steamship and consequent variation in the reduction of trade costs to show that in the first era of globalization, trade promoted economic development in locations with more inclusive political institutions.

Whether temporary trade protections can support industrial development is an important question for both trade economists and policymakers. Providing an "existence result" - protection can promote industrial development - Juhász (2018) exploits the Napoleonic blockade, which protected textile producers in northern France from English competition. She finds that the temporary protection provided by the blockade led to mechanization and production in the textile sector. In related work, exploiting historical variation in South Korea and Finland, respectively, Lane (2019) and Mitrunen (2019) present evidence of successful industrial policy.

The impact of access to markets on prices, output, trade volumes, and welfare is among the core empirical questions in trade, and has been studied exploiting quasi-random historical variation in the diffusion of transportation networks. Fogel (1962) and Fogel (1964) famously studied the impact of the railroad (relative to a counterfactual) on the historical development of the US. Building on this work, and incorporating modern trade theory, Donaldson (2012) structurally estimates the impact of market access exploiting variation in the construction of railroads in British Colonial India. Donaldson and Hornbeck (2016) estimate large effects of railroad-provided market access on US land values in the late nineteenth century. Redding and Sturm (2008) find large effects of lost market access in the context of the division of Germany into East and West 16

\section{Urban Economics}

What determines the spatial pattern of urban development? Davis and Weinstein (2002) find evidence consistent with locational fundamentals being very important, finding significant persistence in Japanese city sizes, even in the face of massive shocks. To identify a causal effect of a short-term locational advantage, Bleakley and Lin (2012) exploit the existence of specific portage

\footnotetext{
${ }^{16}$ In related work, Burchardi and Hassan (2013) identify the value of social linkages for economic activity by exploiting quasi-random variation across West German cities in linkages to the East, then observing differential growth following Germany's reunification.
} 
sites on US rivers. These sites were crucial points for historical trade as goods moving on water needed to be transported on land at precisely these sites (e.g., at rapids or water falls). Bleakley and Lin (2012) find that these sites were persistently more densely populated up through the year 2000. This represents compelling evidence of path-dependence in urban development. Redding et al. (2011) provide evidence that spatial equilibria can be shifted, exploiting variation in airport traffic in Germany following reunification. Constraints to urban growth arising from existing construction are studied by Hornbeck and Keniston (2017). They interpret the rapid reconstruction after the Great Boston Fire of 1872 as a sign that prior, outdated buildings imposed negative spillovers and dampened growth.

How transportation networks affect the spatial distribution of economic activities is another empirical question that has been answered using historical natural experiments. Baum-Snow (2007) studies residential sorting between central cities and suburbs, finding that highway construction in the US played a significant role in the declining population in US central cities. Ahlfeldt: et al. (2015) use the separation of Berlin by the Wall (1961-1989) to estimate parameters that govern agglomeration and dispersion forces in a model of urban production and commuting. Heblich et al. (2018) find that the construction of the London Underground was a crucial contributor to the spatial distribution of housing, employment, and the overall growth of Greater London.

\section{Political economy}

Core political economy questions have been answered using historical natural experiments. The role of the media in influencing public opinion, as well as turnout and voting, is a central area of research in this broad field. Several recent papers examine the impact of quasi-random changes in access to information on political outcomes. Strömberg (2004) exploits variation in access to radio to show that better-informed citizens receive more favorable policies. Gentzkow et al. (2011) find that local newspaper entry increased voter turnout, while Gentzkow (2006) finds that the introduction of television reduced voter turnout in the US (due to the crowding out of local news). Adena et al. (2015) study the impact of radio in Weimar and Nazi Germany, finding that exposure to pro-government radio increased support of the democratic regime in the Weimar era, but increased support for the Nazis as well as anti-Semitic acts once the Nazis took power.

Several papers exploit historical natural experiments to study the consequences of political institutions on economic outcomes. Hinnerich and Pettersson-Lidbom (2014) exploit a sharp population threshold determining whether Swedish local governments function as direct or representative democracies. They find that direct democracies spend less on public welfare than representative democracies, perhaps due to elite capture. Miller (2008) considers the importance of who has the right to vote. Exploiting sharp variation in timing of state-level women's suffrage laws, he shows that granting women the right to vote significantly increased public health spending and improved children's health outcomes. Dal Bó and Rossi (2011) examine the impact of legislators' term lengths on their performance in office, exploiting two natural experiments that randomly 
assigned term lengths in the Argentine Congress. They find that longer term lengths increase legislators' effort, because effort takes time to yield payoffs: a longer time horizon in office means a higher likelihood of reaping returns on effort.

Dippel (2014) examines the consequences of the composition of the state - whether a state is made of a homogeneous ethnic group or consists of several different groups. The latter sort of state was often the consequence of colonial policies that forced coexistence upon distinct ethnicities. Exploiting variation in the composition of US Native American reservations, Dippel finds that forced coexistence is associated with significantly worse economic outcomes. Finally, Chaney (2013) considers the importance of the threat of revolt on the allocation of resources and the balance of power, an important parameter in formal political economy models of institutional change. Specifically, he studies religious and military authorities in Egypt in the centuries following the establishment of the Ayyubid dynasty in 1169. In this context, Chaney finds that major floods of the Nile were associated with more transfers to the religious authority and a lower likelihood of replacement. This is consistent with a model in which floods increased the power of religious authorities due to their ability to coordinate a revolt against the military authority.

\section{The Economics of Science and Innovation}

In a series of papers examining the consequences for German science of the expulsion of Jewish scientists under the Nazi regime, Fabian Waldinger is able to shed light on the importance for scientific production of faculty quality (Waldinger, 2010) and peer effects (Waldinger, 2012). The outbreak of WWII provides Waldinger and co-authors with a source of variation allowing them to identify the importance of physical capital (Waldinger. 2016) as well as access to frontier knowledge (Iaria et al. 2018) in scientific production. The arrival of German scientists in the US is also a useful source of variation to study the impact of frontier scientists on innovation (Moser et al. 2014).

The importance of intellectual property rights for scientific output - and creative output more generally - has been examined in a series of papers by Petra Moser. She and he co-authors find that stringent protection of intellectual property rights involves a clear trade off. On the one hand, intellectual property rights can encourage creative activity (Giorcelli and Moser, 2019); on the other hand, intellectual property rights can limit follow-on innovation (Moser and Voena, 2012), as well as scientific output (Moser and Biasi, 2019). Watzinger et al. (2019) show that in 1956, when the antitrust authorities forced Bell to license all its existing patents royalty-free, this had a positive effect on innovation, but only in sectors where Bell did not maintain a monopolistic position.

Hanlon (2015) provides an empirical test of one of the most influential theories of technical change: technology should be developed endogenously to complement abundant inputs (as argued in the work of Hicks, 1932, and Habbakuk, 1962, and more recently by Acemoglu, 2002). In his work, Hanlon (2015) identifies a causal effect of input relative abundance on complementary directed technical change by exploiting the sharp decline in (Southern) American cotton imports to 
Britain during the US Civil War. Hanlon finds that the sharp, unanticipated change in relative Indian cotton abundance indeed induced the development of complementary technology - perhaps the clearest example of directed technical change that economists have identified.

\section{Macroeconomics}

Fundamental questions in macroeconomics have been answered by exploiting historical natural experiments (see also Fuchs-Schündeln and Hassan, 2016 for a review of this literature). The impact of monetary policy on real economic outcomes has been identified from sharp historical variation in the money supply, argued by the researchers to have been exogenous (see Friedman. 2005 and Velde, 2009). Romer and Romer (2004) identify plausibly exogenous changes in monetary policy by closely examining narrative records from Federal Open Market Committee meetings. All of this work finds large effects of monetary policy on real economic outcomes.

The impact of fiscal policy on output has been studied by Barro and Redlick (2011) and Ramey (2011), who exploit variation in government spending arising from (arguably exogenous) war needs. They find significant crowding out of private economic activity by government spending. Relying on a close reading of the narrative record (presidential speeches and Congressional reports), Romer and Romer (2010) find large contractionary effects of plausibly exogenous tax increases.

Preferences driving savings and consumption decisions have been estimated from historical quasi-experimental variation as well. Hausman (2016) exploits quasi-random variation in eligibility for US military veterans' payments to identify the marginal propensity to consume during the Great Depression. Imbens et al. (2001) study the impact of windfall earnings on consumption and savings by examining the behavior of lottery winners. Fuchs-Schündeln and Schündeln (2005) exploit exogenous variation in income risk produced by the reunification of Germany to estimate precautionary savings accounting for self-selection into riskier occupations.

\subsection{Experiments to Understand Contemporary Outcomes}

Work in this category of papers aims to identify historical determinants of contemporary outcomes, often contemporary economic development. We organize this section by the historical causal driver, thus illustrating the broad range of factors studied using historical natural experiments (a large part of this literature is also reviewed by Nunn, 2009).

\section{Colonial Experience}

A range of work establishes causal effects of the colonial experience on contemporary development outcomes. As discussed above, Acemoglu et al. (2001) and Acemoglu et al. (2002) provide evidence that settler mortality shaped subsequent political institutions, and thus economic growth. Feyrer and Sacerdote (2009) exploit quasi-random variation in wind direction and wind 
speed - which affected when an island would be colonized, and thus who was likely to colonize it - to provide evidence that the identity of the colonist matters for subsequent development. Iyer (2010), Bruhn and Gallego (2012), and Banerjee and Iyer (2005) argue that specific policy choices of colonists affected long run development. This work is closely related to the research of La Porta et al. (1998) and La Porta et al. (2008), who argue that a country's legal tradition - common law or civil - is significantly shaped by the colonial experience, and has important consequences for economic outcomes.

Dell (2010) and Lowes and Montero (2018) examine sharp geographic discontinuities in exposure to specific colonial extractive institutions (the Potosí mining mita and the Congo's extractive rubber concessions, respectively). Regression discontinuity evidence suggests that colonial practices persistently, negatively affected development outcomes in these setting. Not all colonial action was harmful to economic activity in the long-run. In a within-country analysis, Dell and Olken (Forthcoming) find that greater extraction by the Dutch on Java is associated with greater economic development today; Jia (2014a) finds that the colonial treaty ports in China (forcibly extracted by Western Powers from the Chinese) exhibit greater economic development today than very similar locations that were not established as treaty ports.

\section{The Slave Trade}

The slave trade was unquestionably devastating for peoples and societies in Africa and in the New World. One naturally wonders: did this immense economic extraction persistently affect economic outcomes in Africa today? One can imagine different relationships between slavery and development: on the one hand, slaving may have destroyed local institutions (formal and informal) and disincentivized long-term investments (in physical or human capital), reducing wealth, with persistent negative consequences. On the other hand, if slaving was associated with local investments in political, economic, and commercial infrastructure, locations with intense slaving might have performed better than areas in the neighboring hinterlands (though, to be clear, perhaps worse than in a counterfactual scenario with no slaving at all).

Nunn (2008b) identifies a significant, negative causal effect of the intensity of the slave trade on contemporary economic development in Africa. To measure the intensity of the slave trade at the country level, he first collects historical data on the ethnicities of slaves shipped and traded. He then links these data to ethnic homelands, and ethnic homelands to contemporary country boundaries. He finds that countries from which more slaves were extracted (relative to land area) remained significantly poorer in the year 2000 (Nunn and Wantchekon, 2011 present evidence that contemporary levels of trust in Africa have also been affected by the slave trade). To more credibly identify a causal relationship, Nunn exploits variation in distance to the major slavereceiving ports: some locations in Africa were intensely traded not because of their own innate characteristics, but because they happened to be closer to the slave-receiving ports. Using distance to slave-receiving ports as an instrument for the intensity of the slave trade, Nunn continues to 
find a negative effect of the slave trade on economic development. Related work by Nunn studies the impact of slave holding in the US on long-run economic outcomes (Nunn, 2008a).

\section{Disease Environment}

The impact of geography and the associated disease environment on development has been argued perhaps most famously by Jeffrey Sachs (see, for example, Bloom and Sachs, 1998). Acemoglu and Johnson (2007) show that the worldwide improvement of life expectancy starting in the 1940s, due to more effective public health measures and pharmaceuticals, has produced population growth but not improvements in income per capita. Recent work by Marcella Alsan (2015) has provided some of the clearest causal evidence of Africa's specific disease environment affecting economic development. Alsan exploits geographic variation in the suitability of the environment for the Tze Tze fly, which carries a parasite that sickens humans and kills livestock. She finds that disease environment shaped technological progress and political organization in Sub-Saharan Africa, with persistent consequences for economic development.

\section{Leadership}

The role of individual leaders in shaping economic outcomes, and shaping the course of history more generally, is an important question across the social sciences. While it is easy to find anecdotal evidence linking individual political leaders to important policy choices and economic development outcomes (e.g., Deng Xiaoping's decision to open the Chinese economy), it is difficult to identify a credible causal link from individuals to economic outcomes (perhaps Deng Xiaoping's choice was endogenous with respect to the economic opportunities facing the Chinese economy). To identify a causal effect of leaders, Jones and Olken (2005) exploit the quasi-random deaths of leaders. They find that when a leader happens to die, growth trajectories significantly change this is particularly true, as one would expect, for autocrats, who did not face tight formal political constraints. Besley et al. (2011) exploit similar variation to show that leaders' education matters for economic growth as well.

\section{Genetic diversity}

Ashraf and Galor (2013) advance the hypothesis that economic development outcomes reflect deeply rooted genetic differences across societies. They argue that a moderate level of genetic diversity should promote economic development: on the one hand, more diversity makes it more likely that the right traits are available to develop or adopt a particular technology. On the other hand, too much diversity can generate distrust and conflict among differing people. To test their hypothesis, the authors exploit the natural (quasi-experimental) variation in genetic diversity across societies arising from humans' spread around the world "Out of Africa". As founders left the original human groups to establish new groups, these groups would be ever less diverse. 
Thus, the homeland of humans (Africa) is extremely diverse - too diverse according to the authors, and thus relatively poor. Eurasia is moderately diverse - and relatively rich. And, the Americas (i.e., native American societies) are very genetically homogeneous - too homogeneous according to the authors, and again, relatively poor.

\section{Historical Political Experience of One's Ancestors}

Several recent papers exploit historical natural experiments to identify the persistent effects of ancestors' historical political experiences on contemporary culture and economic development outcomes. Guiso et al. (2016) identify a historical source of variation in local culture ("civic capital"): the experience of self-governance in the city-states of medieval Italy. They exploit a source of quasi-random historical variation in self-governance: the presence of a bishop in the year 1000, which made self-governance more likely in northern Italian towns. Lowes et al. (2017) show that historical experience of a centralized state (the Kuba Kingdom) persistently affected the social norms of the descendants of its inhabitants. Heldring (2018) finds that villages that had a longer experience of a historical centralized state in Rwanda exhibit more adherence to state policy. This produced differentially more violence when the Rwandan government mobilized citizens for mass killing and less violence when the government pursued peace.

Putterman and Weil (2010) show that countries with longer histories of developed states are richer today and that individuals descended from regions with a longer experience of organized states are higher in their current home countries' income distributions. Michalopoulos and Papaioannou (2013) find that pre-colonial political centralization of local ethnic groups is positively associated with regional development in Africa.

\section{Challenges to the analysis of historical natural experiments}

Each category of work in our taxonomy is subject to particular, historically relevant empirical critiques.

\subsection{Experiments to Understand History}

Research in our category (1) aims to exploit quasi-experimental variation to make more credible causal statements about historical processes. This sort of work, we believe, is particularly susceptible to the critique of "looking under the lamppost": the economic historian may miss important aspects of the historical process of interest due to the study a component of it that exhibits useful identifying variation. Our work (Cantoni and Yuchtman, 2014) is one target of such critique: while we aim to study the Commercial Revolution - a process beginning in Northern Italy in the Middle Ages - we study market establishment in the Holy Roman Empire several centuries after 
the Commercial Revolution began. We argue for the applicability of our findings to the broader process of the Commercial Revolution, but the critique is well-taken.

Another concern specific to this category of work is that establishing the exogeneity of a quasiexperimental treatment can amount to arguing for the inexplicability of the precise historical variable of interest. The work of Squicciarini and Voigtländer (2015) is exposed to this critique: the authors link upper-tail human capital - which is measured using the proxy variable of subscriptions to Diderot's Encyclopedie - to industrialization and growth in France. Yet, the precise explanatory variable of interest varies in a manner that is unexplained. The authors show that the distribution of subscribers is "balanced" on many dimensions suggesting that they can identify a causal effect - much to the experiment's benefit, but not to the benefit of the historian wishing to understand the distribution of human capital across France.

\subsection{Experiments to Understand Economics}

Research in category (2) is subject to the sorts of concerns raised by Heckman (2005) and Deaton (2010) about quasi-experimental work more generally. One can identify a causal effect from a clean experiment, but to understand socioeconomic processes, one typically needs to go beyond estimating a single causal effect to understand how that effect relates to economic theory. Work in category (2) thus often offers very nice "existence" results, without necessarily providing insight into the mechanisms producing a particular empirical finding. For example, the work of Juhász (2018) provides an extremely important finding, indicating the potential for temporary trade protection to promote industrial development. However, it does not tell us why protection worked in this case, while it appears to fail in other cases (only a short discussion is provided in the paper).

Whether causal parameter estimates from a particular historical natural experiment are useful or interesting to an economist interested in contemporary policy questions is also likely to vary significantly across settings and applications. For example, labor supply elasticities estimated from a "clean" historical experiment (e.g., the introduction of a new tax) may not be relevant for contemporary policy recommendations, in very different institutional and cultural settings. While clean parameter estimates and existence results such as those in Bernhofen and Brown (2004) or by Davis and Weinstein (2002) can inform broad classes of models, economic theory and an understanding of institutional details are needed to draw general conclusions from specific historical settings.

\subsection{Experiments to Understand Contemporary Outcomes}

Research in category (3), causally linking past variation to contemporary outcomes (either directly or through single endogenous regressors in an instrumental variables model), is subject to a range of threats from historical contingency. As we discuss in more detail in Cantoni and Yuchtman (2020), the arrival of time-varying shocks makes it very difficult to trace out simple causal effects 
from even the cleanest natural experiment. Estimated treatment effects are typically historicallycontingent, or in some cases, mix up time-contingent effects of instrument, regressor of interest, and perhaps intermediate outcomes. While there is much to like, and learn from, work linking past variation to the present, it requires extremely careful historical work all along the causal chain, not merely understanding the moment of randomization itself.

All of these critiques are best resolved by applying economic theory and deep historical understanding to one's quasi-experimental research. This helps one generalize a local average treatment effect; it helps one understand how historical mechanisms act over time.

\section{Concluding thoughts}

In this piece we have traced out the development of a methodology, the historical natural experiment, that has stimulated work in the field of economic history and also provided a tool that is applied across fields in economics. It has produced some of the most influential recent empirical work not only in economic history but also in subfields from economic development, to trade, to urban economics, labor economics, macroeconomics, and beyond.

We have described the accomplishments of this large body of research, and briefly raised concerns with the application of the methodology. Both strengths and weaknesses, we believe, have their roots in the intellectual history of the rise of the historical natural experiment as an empirical tool. The strengths lie in the linking of extraordinary ambition in asking fundamental research questions with sharp research design that allows for more credible causal statements. The weaknesses lie in the temptation to conduct very reduced form empirical analysis, and thus very narrow historical analysis, once a (seemingly) clean source of historical variation is identified. The weaknesses, we note, are ironically reinforced by the incorporation of economic history papers into an ever-wider range of economics field course syllabi - while concomitantly stand-alone economic history courses (once required in PhD programs around the world) disappear. We emphasize that the analysis of historical natural experiments is a bridge: historians must learn to do good applied econometrics, and non-historians must cross over and develop tools of historical analysis. 


\section{References}

Aaronson, Daniel and Bhashkar Mazumder, "The Impact of Rosenwald Schools on Black Achievement," Journal of Political Economy, 2011, 119 (5), 821-888.

Abramitzky, Ran, "Economics and the Modern Economic Historian," Journal of Economic History, 2015, 75 (4), 1240-1251.

_, Adeline Delavande, and Luis Vasconcelos, "Marrying Up: The Role of Sex Ratio in Assortative Matching," American Economic Journal: Applied Economics, July 2011, 3 (3), 124-157.

_, Leah P. Boustan, and Katherine Eriksson, "Europe's Tired, Poor, Huddled Masses: SelfSelection and Economic Outcomes in the Age of Mass Migration," American Economic Review, 2012, 102 (5), 1832-1856.

_ , _ , , , James J. Feigenbaum, and Santiago Pérez, "Automated Linking of Historical Data," NBER Working Paper Series, May 2019, 25825.

Acemoglu, Daron, “Directed Technical Change," Review of Economic Studies, October 2002, 69 (4), 781-809.

- and James A. Robinson, Why Nations Fail: The Origins of Power, Prosperity, and Poverty, New York: Crown, August 2012.

- and Simon Johnson, "Disease and Development: The Effect of Life Expectancy on Economic Growth," Journal of Political Economy, 2007, 115 (6), 925-985.

_ , Davide Cantoni, Simon Johnson, and James A. Robinson, "The Consequences of Radical Reform: The French Revolution," American Economic Review, December 2011, 101 (7), 3286-3307.

_, Simon Johnson, and James A. Robinson, “The Colonial Origins of Comparative Development: An Empirical Investigation," American Economic Review, December 2001, 91 (5), 13691401.

$\ldots, \ldots$, and $\_,$"Reversal of Fortune: Geography and Institutions in the Making of the Modern World Income Distribution," Quarterly Journal of Economics, November 2002, 117 (4), 1231-1294.

_, , , and _ , "The Rise of Europe: Atlantic Trade, Institutional Change, and Economic Growth," American Economic Review, June 2005, 95 (3), 547-579.

_, Tarek A. Hassan, and James A. Robinson, "Social Structure and Development: A Legacy of the Holocaust in Russia," Quarterly Journal of Economics, May 2011, 126 (2), 895-946.

Adena, Maja, Ruben Enikolopov, Maria Petrova, Veronica Santarosa, and Ekaterina Zhuravskaya, "Radio and the Rise of The Nazis in Prewar Germany," Quarterly Journal of Economics, November 2015, 130 (4), 1885-1939.

Ahlfeldt, Gabriel M., Stephen J. Redding, Daniel M. Sturm, and Nikolaus Wolf, "The Economics of Density: Evidence From the Berlin Wall," Econometrica, 2015, 83 (6), 2127-2189.

Aizer, Anna, Shari Eli, Joseph Ferrie, and Adriana Lleras-Muney, "The Long-Run Impact of Cash Transfers to Poor Families," American Economic Review, 2016, 106 (4), 935-971. 
Alesina, Alberto and Nicola Fuchs-Schündeln, "Good Bye Lenin (or Not?): The Effect of Communism on People's Preferences," American Economic Review, 2007, 97 (4), 1507-1528.

_, Paola Giuliano, and Nathan Nunn, "On the Origins of Gender Roles: Women and the Plough," Quarterly Journal of Economics, 2013, 128 (2), 469-530.

Almond, Douglas, "Is the 1918 Influenza Pandemic Over? Long-Term Effects of In Utero Influenza Exposure in the Post-1940 U.S. Population," Journal of Political Economy, 2006, 114 (4), $672-712$.

_ , Hilary W. Hoynes, and Diane Whitmore Schanzenbach, "Inside the War on Poverty: The Impact of Food Stamps on Birth Outcomes," Review of Economics and Statistics, 2011, 93 (2), 387403.

_ , Lena Edlund, and Mårten Palme, "Chernobyl's Subclinical Legacy: Prenatal Exposure to Radioactive Fallout and School Outcomes in Sweden," Quarterly Journal of Economics, 11 2009, 124 (4), 1729-1772.

Alsan, Marcella, "The Effect of the Tsetse Fly on African Development," American Economic Review, 2015, 105 (1), 382-410.

- and Claudia Goldin, "Watersheds in Child Mortality: The Role of Effective Water and Sewerage Infrastructure, 1880-1920," Journal of Political Economy, 2019, 127 (2), 586-638.

- and Marianne Wanamaker, "Tuskegee and the Health of Black Men," Quarterly Journal of Economics, February 2018, 133 (1), 407-455.

Aneja, Abhay P. and Carlos F. Avenancio-Leon, "The Effect of Political Power on Labor Market Inequality: Evidence from the 1965 Voting Rights Act," September 2019. Unpublished, UC Berkeley.

Angrist, Joshua D., "Lifetime earnings and the Vietnam era draft lottery: evidence from social security administrative records," American Economic Review, 1990.

- and Alan B. Krueger, "Does compulsory school attendance affect schooling and earnings?," Quarterly Journal of Economics, 1991, 106 (4), 979-1014.

_ and _ ,"Empirical Strategies in Labor Economics," in Orley Ashenfelter and David Card, eds., Handbook of Labor Economics, Vol. 3A, Elsevier, 1999, chapter 23.

- and Jörn-Steffen Pischke, "The Credibility Revolution in Empirical Economics: How Better Research Design is Taking the Con out of Econometrics," Journal of Economic Perspectives, May 2010, 24 (2), 3-30.

Ashraf, Quamrul and Oded Galor, "The 'Out of Africa' Hypothesis, Human Genetic Diversity, and Comparative Economic Development," American Economic Review, February 2013, 103 (1), $1-46$.

Bailey, Martha J., "More Power to the Pill: The Impact of Contraceptive Freedom on Women's Life Cycle Labor Supply," Quarterly Journal of Economics, February 2006, 121 (1), 289-320. 
- , “Momma's Got the Pill': How Anthony Comstock and Griswold v. Connecticut Shaped US Childbearing," American Economic Review, 2010, 100 (1), 98-129.

Banerjee, Abhijit V. and Esther Duflo, "The Experimental Approach to Development Economics," Annual Review of Economics, 2009, 1 (1), 151-178.

_ and _ , "The Experimental Approach to Development Economics," Annual Review of Economics, September 2009, 1 (1), 151-178.

- and Lakshmi Iyer, "History, Institutions, and Economic Performance: The Legacy of Colonial Land Tenure Systems in India," American Economic Review, 2005, 95 (4), 1190-1213.

_, Esther Duflo, Gilles Postel-Vinay, and Tim Watts, "Long-Run Health Impacts of Income Shocks: Wine and Phylloxera in Nineteenth-Century France," Review of Economics and Statistics, November 2010, 92 (4), 714-728.

Barro, Robert J., "Economic Growth in a Cross Section of Countries," Quarterly Journal of Economics, 1991, 106 (2), 407-443.

- and Charles J. Redlick, "Macroeconomic Effects From Government Purchases and Taxes," Quarterly Journal of Economics, February 2011, 126 (1), 51-102.

Baten, Jörg, Dorothee Crayen, and Hans-Joachim Voth, "Numeracy and the Impact of High Food Prices in Industrializing Britain, 1780-1850," Review of Economics and Statistics, 2014, 96 (3), 418430.

Bauernschuster, Stefan, Anastasia Driva, and Erik Hornung, "Bismarck's Health Insurance and the Mortality Decline," 2020. Forthcoming, Journal of the European Economic Association.

Baum-Snow, Nathaniel, "Did Highways Cause Suburbanization?," Quarterly Journal of Economics, May 2007, 122 (2), 775-805.

Becker, Sascha O. and Ludger Woessmann, "Was Weber Wrong? A Human Capital Theory of Protestant Economic History," Quarterly Journal of Economics, May 2009, 124 (2), 531-596.

Bernhofen, Daniel M. and John C. Brown, "A Direct Test of the Theory of Comparative Advantage: The Case of Japan," Journal of Political Economy, 48-67 2004, 112 (1).

_ and _ , "An Empirical Assessment of the Comparative Advantage Gains from Trade: Evidence from Japan," American Economic Review, March 2005, 95 (1), 208-225.

Besley, Timothy, Jose G. Montalvo, and Marta Reynal-Querol, "Do Educated Leaders Matter?," Economic Journal, August 2011, 121 (554), F205-F227.

Bianchi, Marco, Björn R. Gudmundsson, and Gylfi Zoega, "Iceland's Natural Experiment in Supply-Side Economics," American Economic Review, December 2001, 91 (5), 1564-1579.

Bleakley, Hoyt, "Disease and Development: Evidence from Hookworm Eradication in the American South," Quarterly Journal of Economics, 2007, 122 (1), 73-117.

_ and Jeffrey Lin, "Portage and Path Dependence," Quarterly Journal of Economics, May 2012, 127 (2), 587-644. 
- and Joseph Ferrie, "Land Openings on the Georgia Frontier and the Coase Theorem in the Short- and Long-Run," January 2014. Unpublished, Northwestern University.

_ and _, "Shocking Behavior: Random Wealth in Antebellum Georgia and Human Capital Across Generations," Quarterly Journal of Economics, 2016, 131 (3), 1455-1495.

Bloom, David E. and Jeffrey D. Sachs, "Geography, Demography, and Economic Growth in Africa," Brookings Papers on Economic Activity, 1998.

Botticini, Maristella and Zvi Eckstein, "From Farmers to Merchants, Conversions and Diaspora: Human Capital and Jewish History," Journal of the European Economic Association, September 2007, 5 (5), 885-926.

Boustan, Leah P., "Was Postwar Suburbanization "White Flight"? Evidence from the Black Migration*," Quarterly Journal of Economics, 2010, 125 (1), 417-443.

Brainerd, Elizabeth, "The Lasting Effect of Sex Ratio Imbalance on Marriage and Family: Evidence from World War II in Russia," Review of Economics and Statistics, May 2017, 99 (2), 229-242.

Bruhn, Miriam and Francisco Gallego, "Good, Bad and Ugly Colonial Activities: Do They Matter for Economic Development?," Review of Economics and Statistics, May 2012, 94 (2), 433-461.

Bühler, Mathias, "Property Rights, Resources, and Wealth: The Public Grazing Solution in the United States," August 2019. Unpublished, University of Munich.

Burchardi, Konrad B. and Tarek A. Hassan, "The economic impact of social ties: Evidence from german reunification," Quarterly Journal of Economics, 2013, 128 (3), 1219-1271.

Cantoni, Davide, "The Economic Effects of the Protestant Reformation: Testing the Weber Hypothesis in the German Lands," Journal of the European Economic Association, August 2015, 13 (4), 561-598.

- and Noam Yuchtman, "Medieval Universities, Legal Institutions, and the Commercial Revolution," Quarterly Journal of Economics, May 2014, 129 (2), 823-887.

_ and _, "Historical Contingencies, Econometric Problems: The Analysis of Natural Experiments in Economic History," 2020. Unpublished Working Paper, University of Munich.

_, Jeremiah Dittmar, and Noam Yuchtman, "Religious Competition and Reallocation: The Political Economy of Secularization in the Protestant Reformation," Quarterly Journal of Economics, November 2018, 133 (4), 2037-2096.

Card, David, "The Impact of the Mariel Boatlift on the Miami Labor Market," ILR Review, 1990, 43 (2), 245-257.

Cascio, Elizabeth U. and Ebonya Washington, "Valuing the Vote: The Redistribution of Voting Rights and State Funds following the Voting Rights Act of 1965," Quarterly Journal of Economics, February 2014, 129 (1), 379-433.

Chaney, Eric, "Revolt on the Nile: Economic Shocks, Religion, and Political Power," Econometrica, 2013, 81 (5), 2033-2053. 
Clay, Karen, Werner Troesken, and Michael Haines, "Lead and Mortality," Review of Economics and Statistics, July 2014, 96 (3), 458-470.

Craft, Erik D., "The Value of Weather Information Services for Nineteenth-Century Great Lakes Shipping," American Economic Review, 1998, 88 (5), 1059-1076.

Cutler, David, Winnie Fung, Michael Kremer, Monica Singhal, and Tom Vogl, "Early-Life Malaria Exposure and Adult Outcomes: Evidence from Malaria Eradication in India," American Economic Journal: Applied Economics, 2010, 2 (2), 72-94.

Dal Bó, Ernesto and Martín A. Rossi, "Term Length and the Effort of Politicians," The Review of Economic Studies, October 2011, 78 (4), 1237-1263.

Davis, Donald R. and David E. Weinstein, "Bones, Bombs, and Break Points: The Geography of Economic Activity," American Economic Review, December 2002, 92 (5), 1269-1289.

Deaton, Angus, "Instruments, randomization, and learning about development," Journal of Economic Literature, 2010, 48 (2), 424-455.

Dell, Melissa, “The Persistent Effects of Peru's Mining Mita,” Econometrica, 2010, 78 (6), 1863-1903.

- and Benjamin A. Olken, "The Development Effects of the Extractive Colonial Economy: The Dutch Cultivation System in Java," Review of Economic Studies, Forthcoming.

Diamond, Jared, Guns, Germs, and Steel: The Fates of Human Societies, New York: W.W. Norton, 1997.

- and James A. Robinson, eds, Natural Experiments of History, Cambridge, Mass.: Harvard University Press, 2010.

Dippel, Christian, "Forced coexistence and economic development: Evidence from native american reservations," Econometrica, 2014, 82 (6), 2131-2165.

Dittmar, Jeremiah, "Ideas, Technology, and Economic Change: The Impact of the Printing Press," Quarterly Journal of Economics, 2011, 126 (3), 1133-1172.

- and Skipper Seabold, "New Media and Competition: Printing and Europe's Transformation After Gutenberg," 2018. Unpublished, London School of Economics.

Donaldson, Dave, "Railroads of the Raj: Estimating the Impact of Transportation Infrastructure," Working Paper, January 2012, pp. 1-51.

- and Richard Hornbeck, "Railroads and American Economic Growth: A "Market Access" Approach," Quarterly Journal of Economics, May 2016, 131 (2), 799-858.

Dube, Arindrajit, Ethan Kaplan, and Suresh Naidu, "Coups, Corporations, and Classified Information," Quarterly Journal of Economics, August 2011, 126 (3), 1375-1409.

Duflo, Esther, "Schooling and labor market consequences of school construction in Indonesia: Evidence from an unusual policy experiment," American Economic Review, 2001, 91 (4), 795-813. 
Engerman, Stanley L. and Kenneth L. Sokoloff, "Factor Endowments, Institutions, and Differential Paths of Growth Among New World Economies: A View from Economic Historians of the United States," in Stephen Haber, ed., How Latin America Fell Behind, Palo Alto, Calif.: Stanford University Press, 1997.

Feigenbaum, James J. and Martin Rotemberg, "Information and Investment: Impacts of the Introduction of Rural Free Delivery," n.d. Boston University working paper.

Feldstein, Martin, "The Effect of Marginal Tax Rates on Taxable Income: A Panel Study of the 1986 Tax Reform Act," Journal of Political Economy, 1995, 103 (3), 551-572.

Fernihough, Alan and Kevin H. O'Rourke, "Coal and the European Industrial Revolution," NBER, 2014, 19802.

Fetter, Daniel K. and Lee M. Lockwood, “Government Old-Age Support and Labor Supply: Evidence from the Old Age Assistance Program," American Economic Review, 2018, 108 (8), 21742211.

Feyrer, James, "Distance, Trade, and Income - The 1967 to 1975 Closing of the Suez Canal as a Natural Experiment," NBER Working Paper Series, 2009, 15557.

- and Bruce Sacerdote, "Colonialism and Modern Income: Islands as Natural Experiments," Review of Economics and Statistics, November 2009, 91 (2), 245-262.

Finan, Frederico, Benjamin A. Olken, and Rohini Pande, "The Personnel Economics of the Developing State," in Abhijit Banerjee and Esther Duflo, eds., Handbook of Field Experiments, Vol. 2, North Holland, 2017.

Fogel, Robert W., "A Quantitative Approach to the Study of Railroads in American Economic Growth: A Report of Some Preliminary Findings," Journal of Economic History, 1962, 22 (2), 163197.

_, Railroads and American Economic Growth: Essays in Econometric History, Baltimore: Johns Hopkins Press, 1964.

- and Stanley L. Engerman, Time on the Cross: The Economics of American Negro Slavery, New York: W.W. Norton, 1974.

Fouka, Vasiliki, Soumyajit Mazumder, and Marco Tabellini, "From Immigrants to Americans: Race and Assimilation during the Great Migration," June 2019. Unpublished, Stanford University.

Friedman, Milton, "A Natural Experiment in Monetary Policy Covering Three Episodes of Growth and Decline in the Economy and the Stock Market," Journal of Economic Perspectives, 2005, 19 (4), 145-150.

- and Anna J. Schwartz, A Monetary History of the United States, 1867-1906., Princeton, NJ: Princeton University Press, 1963.

Frydman, Carola and Raven E. Saks, "Executive Compensation: A New View from a Long-Term Perspective, 1936-2005," Review of Financial Studies, 2010, 23 (5), 2099-2138. 
Fuchs-Schündeln, Nicola and Matthias Schündeln, "Precautionary Savings and Self-Selection: Evidence from the German Reunification "Experiment"," Quarterly Journal of Economics, 2005, $120,1085-1120$.

- and Tarek A. Hassan, "Natural Experiments in Macroeconomics," in John B. Taylor and Harald Uhlig, eds., Handbook of Macroeconomics, Vol. 2a, Elsevier, 2016, pp. 923-1012.

Galor, Oded and Ömer Özak, “The Agricultural Origins of Time Preference," American Economic Review, 2016, 106 (10), 3064-3103.

Gelber, Alexander M., Adam Isen, and Jae Song, "The Effect of Pension Income on Elderly Earnings: Evidence from Social Security and Full Population Data," May 2016. UC-San Diego working paper.

Gentzkow, Matthew, "Television and Voter Turnout," Quarterly Journal of Economics, August 2006, 121 (3), 931-972.

_ , Jesse M. Shapiro, and Michael Sinkinson, "The Effect of Newspaper Entry and Exit on Electoral Politics," American Economic Review, 2011, 101 (7), 2980-3018.

Gertler, Paul, "Do Conditional Cash Transfers Improve Child Health? Evidence from PROGRESA's Control Randomized Experiment," American Economic Review, 2004, 94 (2), 336-341.

Giorcelli, Michela, "The Long-Term Effects of Management and Technology Transfers," American Economic Review, 2019, 109 (1), 1-33.

_ and Petra Moser, "Copyright and Creativity: Evidence from Italian Operas," November 2019. NYU working paper.

Giuliano, Paola and Antonio Spilimbergo, "Growing Up in a Recession," Review of Economic Studies, 2014, 81 (2), 787-817.

Goldin, Claudia and Lawrence F. Katz, “The power of the pill: Oral contraceptives and women's career and marriage decisions," Journal of Political Economy, 2002, 110 (4), 730-770.

Goñi, Marc, "Assortative Matching at the Top of the Distribution: Evidence from the World's Most Exclusive Marriage Market," August 2018. Unpublished.

Goodman-Bacon, Andrew, "Public Insurance and Mortality: Evidence from Medicaid Implementation," Journal of Political Economy, 2018, 126 (1), 216-262.

Grönqvist, Hans, J. Peter Nilsson, and Per-Olof Robling, “Understanding How Early Lead Exposure Affect Children's Life-Trajectories," 2020. Forthcoming, Journal of Political Economy.

Guiso, Luigi, Paola Sapienza, and Luigi Zingales, "Long-Term Persistence," Journal of the European Economic Association, December 2016, 14 (6), 1401-1436.

Habbakuk, H. J., American and British Technology in the Nineteenth Century: Search for Labor Saving Inventions, Cambridge: Cambridge University Press, 1962.

Hanlon, W. Walker, "Necessity is the Mother of Invention: Input Supplies and Directed Technical Change," Econometrica, January 2015, 83 (1), 67-100. 
Hausman, Joshua K., "Fiscal Policy and Economic Recovery: The Case of the 1936 Veterans' Bonus," American Economic Review, April 2016, 106 (4), 1100-1143.

_ , Paul W. Rhode, and Johannes F. Wieland, "Recovery from the Great Depression: The Farm Channel in Spring 1933," American Economic Review, 2019, 109 (2), 427-472.

Heblich, Stephan, Stephen J. Redding, and Daniel M. Sturm, "The Making of the Modern Metropolis: Evidence from London," September 2018. LSE working paper.

Heckman, James J., “The Scientific Model of Causality," Sociological Methodology, 2005, 35 (1), 1-97.

Heldring, Leander, “The Origins of Violence in Rwanda,” February 2018. Tilburg University working paper.

— , James A. Robinson, and Sebastian Vollmer, "The Long-Run Impact of the Dissolution of the English Monasteries," August 2017. Unpublished.

Hendricks, Kenneth and Robert H. Porter, "An Empirical Study of an Auction with Asymmetric Information," American Economic Review, 1988, 78 (5), 865-883.

_, Joris Pinkse, and Robert H. Porter, "Empirical Implications of Equilibrium Bidding in FirstPrice, Symmetric, Common Value Auctions," Review of Economic Studies, 2003, 70 (1), 115-145.

Hicks, John R., The Theory of Wages, New York: Macmillan, 1932.

Hinnerich, Bjorn Tyrefors and Per Pettersson-Lidbom, "Democracy, Redistribution, and Political Participation: Evidence From Sweden 1919-1938," Econometrica, May 2014, 82 (3), 961-993.

Hornbeck, Richard, “Barbed Wire: Property Rights and Agricultural Development," Quarterly Journal of Economics, May 2010, 125 (2), 767-810.

_ , "The Enduring Impact of the American Dust Bowl: Short- and Long-run Adjustments to Environmental Catastrophe.," American Economic Review, 2012, 102 (4), 1477-1507.

- and Daniel Keniston, "Creative Destruction: Barriers to Urban Growth and the Great Boston Fire of 1872," American Economic Review, 2017, 107 (6), 1365-1398.

- and Suresh Naidu, "When the Levee Breaks: Black Migration and Economic Development in the American South," American Economic Review, 2014, 104 (3), 963-90.

Hornung, Erik, "Immigration and the Diffusion of Technology: The Huguenot Diaspora in Prussia," American Economic Review, 2014, 104 (1), 84-122.

Iaria, Alessandro, Carlo Schwarz, and Fabian Waldinger, "Frontier Knowledge and Scientific Production: Evidence from the Collapse of International Science," Quarterly Journal of Economics, 2018, 133 (2), 927-991.

Imbens, Guido W., Donald B. Rubin, and Bruce I. Sacerdote, "Estimating the Effect of Unearned Income on Labor Earnings, Savings, and Consumption: Evidence from a Survey of Lottery Players," American Economic Review, 2001, 91 (4), 778-794. 
Isen, Adam, Maya Rossin-Slater, and W. Reed Walker, "Every Breath You Take - Every Dollar You'll Make: The Long-Term Consequences of the Clean Air Act of 1970," Journal of Political Economy, June 2017, 125 (3), 848-902.

Iyer, Lakshmi, “Direct versus Indirect Colonial Rule in India: Long-Term Consequences," Review of Economics and Statistics, 2010, 92 (4), 693-713.

Iyigun, Murat, "Luther and Suleyman," Quarterly Journal of Economics, November 2008, 123 (4), 1465-1494.

Jaremski, Matthew, "Today's economic history and tomorrow's scholars," Cliometrica, 2020, 14 (1), 169-180.

Jha, Saumitra, "Financial Asset Holdings and Political Attitudes: Evidence from Revolutionary England," Quarterly Journal of Economics, 2015, 103 (3), 1485-1545.

Jia, Ruixue, "The Legacies of Forced Freedom: China's Treaty Ports," Review of Economics and Statistics, October 2014, 96 (4), 596-608.

_ , "Weather Shocks, Sweet Potatoes and Peasant Revolts in Historical China," Economic Journal, March 2014, 124 (575), 92-118.

Jones, Benjamin F. and Benjamin A. Olken, "Do leaders matter? National leadership and growth since World War II," Quarterly Journal of Economics, 2005.

Juhász, Réka, "Temporary Protection and Technology Adoption: Evidence from the Napoleonic Blockade ," American Economic Review, 2018, 108 (11), 3339-3376.

Kline, Patrick and Enrico Moretti, "Local Economic Development, Agglomeration Economies, and the Big Push: 100 Years of Evidence from the Tennessee Valley Authority," Quarterly Journal of Economics, February 2014, 129 (1), 275-331.

Koudijs, Peter, "The Boats That Did Not Sail: Asset Price Volatility in a Natural Experiment," Journal of Finance, 2016, 71 (3), 1185-1226.

- and Hans-Joachim Voth, "Leverage and Beliefs: Personal Experience and Risk-Taking in Margin Lending," American Economic Review, 2016, 106 (11), 3367-3400.

Kremer, Michael, "Population Growth and Technological Change: One Million B.C. to 1990," Quarterly Journal of Economics, August 1993, 108 (3), 681-716.

La Porta, Rafael, Florencio Lopez-de-Silanes, and Andrei Shleifer, "The Economic Consequences of Legal Origins," Journal of Economic Literature, 2008, 46 (2), 285-332.

_, , , , , and Robert W. Vishny, "Law and Finance," Journal of Political Economy, 1998, 106 (6), 1113-1155.

Lane, Nathan, "Manufacturing Revolutions - Industrial Policy and Industrialization in South Korea," 2019. Unpublished, Monash University.

Libecap, Gary D. and Dean Lueck, "The Demarcation of Land and the Role of Coordinating Property Institutions," Journal of Political Economy, 2011, 119 (3), 426-467. 
Lowes, Sara and Eduardo Montero, "Concessions, Violence, and Indirect Rule: Evidence from the Congo Free State," November 2018. Unpublished, Bocconi University.

_, Nathan Nunn, James A. Robinson, and Jonathan L. Weigel, "The Evolution of Culture and Institutions: Evidence from the Kuba Kingdom," Econometrica, July 2017, 85 (4), 1065-1091.

Malmendier, Ulrike and Stefan Nagel, "Depression Babies: Do Macroeconomic Experiences Affect Risk Taking?," Quarterly Journal of Economics, April 2011, 126 (1), 373-416.

Manacorda, Marco, "Child Labor and the Labor Supply of Other Household Members: Evidence from 1920 America," American Economic Review, 2006, 96 (5), 1788-1801.

Mankiw, N. Gregory, David Romer, and David N. Weil, "A Contribution to the Empirics of Economic Growth," Quarterly Journal of Economics, May 1992, 107 (2), 407-437.

Margo, Robert A., "The integration of economic history into economics," Cliometrica, 2018, 12 (3), 377-406.

Matranga, Andrea, "The Ant and the Grasshopper: Seasonality and the Invention of Agriculture," December 2017. Unpublished, New Economic School.

McCloskey, Donald N., "Does the Past Have Useful Economics?," Journal of Economic Literature, 1976, 14 (2), 434-461.

Michalopoulos, Stelios and Elias Papaioannou, "Pre-Colonial Ethnic Institutions and Contemporary African Development," Econometrica, 2013, 81 (1), 113-152.

Miguel, Edward and Michael Kremer, "Worms: Identifying Impacts on Education and Health in the Presence of Treatment Externalities," Econometrica, 2004, 72 (1), 159-217.

Miller, Grant, "Women's Suffrage, Political Responsiveness, and Child Survival in American History," Quarterly Journal of Economics, August 2008, 123 (3), 1287-1327.

Mitchener, Kris J., "The 4D Future of Economic History: Digitally-Driven Data Design," Journal of Economic History, 2015, 75 (4), 1234-1239.

Mitrunen, Matti, "Structural Change and Intergenerational Mobility: Evidence from the Finnish War Reparations," 2019. Unpublished, IIES Stockholm.

Moser, Petra, Alessandra Voena, and Fabian Waldinger, "German Jewish Emigres and US Invention," American Economic Review, 2014, 104 (10), 3222-3255.

_ and _ , "Compulsory Licensing: Evidence from the Trading with the Enemy Act," American Economic Review, 2012, 102 (1), 396-427.

- and Barbara Biasi, "Effects of Copyright on Science: Evidence from the WWII Book Republication Program," November 2019. NYU working paper.

Naidu, Suresh and Noam Yuchtman, "Coercive Contract Enforcement: Law and the Labor Market in Nineteenth Century Industrial Britain," American Economic Review, February 2013, 103 (1), 107-144. 
Nilsson, J. Peter, "Alcohol Availability, Prenatal Conditions, and Long-Term Economic Outcomes," Journal of Political Economy, 2017, 125 (4), 1149-1207.

Nunn, Nathan, "Slavery, Inequality, and Economic Development in the Americas: An Examination of the Engerman-Sokoloff Hypothesis," in Elhanan Helpman, ed., Institutions and Economic Performance, Cambridge, Mass.: Harvard University Press, 2008, pp. 148-180.

_ , “The Long Term Effects of Africa's Slave Trades," Quarterly Journal of Economics, 2008, 123 (1), 139-176.

_ , "The Importance of History for Economic Development," Annual Review of Economics, September 2009, 1 (1), 65-92.

- and Leonard Wantchekon, "The Slave Trade and the Origins of Mistrust in Africa," American Economic Review, 2011, 101 (7), 3221-3252.

- and Nancy Qian, “The Potato's Contribution to Population and Urbanization: Evidence from a Natural Experiment," Quarterly Journal of Economics, 2011, 126 (2), 593-650.

Pascali, Luigi, “The Wind of Change: Maritime Technology, Trade, and Economic Development," American Economic Review, 2017, 107 (9), 2821-2854.

Piketty, Thomas and Emmanuel Saez, "Income Inequality in the United States, 1913-1998," Quarterly Journal of Economics, February 2003.

_, Gilles Postel-Vinay, and Jean-Laurent Rosenthal, "Wealth Concentration in a Developing Economy: Paris and France, 1807-1994," American Economic Review, March 2006, 96 (1), 236-256.

Putterman, Louis and David N. Weil, "Post-1500 Population Flows and The Long-Run Determinants of Economic Growth and Inequality," Quarterly Journal of Economics, November 2010, 125 (4), 1627-1682.

Ramey, Valerie A., "Identifying Government Spending Shocks: It's all in the Timing," Quarterly Journal of Economics, February 2011, 126 (1), 1-50.

Redding, Stephen J. and Daniel M. Sturm, "The Costs of Remoteness: Evidence from German Division and Reunification," American Economic Review, 2008, 98 (5), 1766-1797.

_ , _ , and Nikolaus Wolf, "History and Industry Location: Evidence from German Airports," Review of Economics and Statistics, July 2011, 93 (3), 814-831.

Richardson, Gary and William Troost, "Monetary Intervention Mitigated Banking Panics during the Great Depression: Quasi-Experimental Evidence from a Federal Reserve District Border, 1929-1933," Journal of Political Economy, 2009, 117 (6), 1031-1073.

Romer, Christina D., “The End of Economic History?," Journal of Economic Education, 1994, 25 (1), 49-66.

- and David H. Romer, "A New Measure of Monetary Shocks: Derivation and Implications," American Economic Review, 2004, 94 (4), 1055-1084. 
_ and _ , "The Macroeconomic Effects of Tax Changes: Estimates Based on a New Measure of Fiscal Shocks," American Economic Review, 2010, 100 (3), 763-801.

Rubin, Jared, "Printing and Protestants: An Empirical Test of the Role of Printing in the Reformation," Review of Economics and Statistics, May 2014, 96 (2), 270-286.

Santavirta, Torsten, "How Large Are the Effects from Temporary Changes in Family Environment: Evidence from a Child-Evacuation Program During World War II," American Economic Journal: Applied Economics, 2012, 4 (3), 28-42.

Squicciarini, Mara P. and Nico Voigtländer, "Human Capital and Industrialization: Evidence from the Age of Enlightenment," 2015. Forthcoming, Quarterly Journal of Economics.

Stanley, Marcus, "College Education and the Midcentury GI Bills," Quarterly Journal of Economics, 2003, 118 (2), 671-708.

Stephens, Melvin and Dou-Yan Yang, "Compulsory Education and the Benefits of Schooling," American Economic Review, 2014, 104 (6), 1777-1792.

Strömberg, David, "Radio's impact on public spending," Quarterly Journal of Economics, 2004, 119 (1), 189-221.

Velde, François R., "Chronicle of a Deflation Unforetold," Journal of Political Economy, 2009, 117 (4), 591-634.

Voigtländer, Nico and Hans-Joachim Voth, "Persecution Perpetuated: The Medieval Origins of Anti-Semitic Violence in Nazi Germany," Quarterly Journal of Economics, 2012, 127 (3), 1339-1392.

Voth, Hans-Joachim and Guo Xu, "Patronage for Productivity: Selection and Performance in the Age of Sail," January 2020. Unpublished, UC Berkeley.

Waldinger, Fabian, “Quality Matters: The Expulsion of Professors and the Consequences for PhD Student Outcomes in Nazi Germany," Journal of Political Economy, 2010, 118 (4), 787-831.

_ , "Peer Effects in Science: Evidence from the Dismissal of Scientists in Nazi Germany," Review of Economic Studies, April 2012, 79 (2), 838-861.

_ , "Bombs, Brains, and Science: The Role of Human and Physical Capital for the Production of Scientific Knowledge," Review of Economics and Statistics, 2016, 98 (5), 811-831.

Watzinger, Martin, Thomas A. Fackler, Markus Nagler, , and Monika Schnitzer, "How Antitrust Enforcement Can Spur Innovation: Bell Labs and the 1956 Consent Decree," February 2019. Unpublished, University of Munich.

Xu, Guo, "The Costs of Patronage: Evidence from the British Empire," American Economic Review, 2018, 108 (11), 3170-3198.

Zhang, Kaixuan, Zejiang Shen, Jie Zhou, and Melissa Dell, "Information Extraction from Text Regions with Complex Tabular Structure," 2019. Conference proceedings, NeurIPS Document Intelligence Workshop. 